\title{
Introduction to Celtic languages
}

\section{Bloch-Trojnar, Maria}

de Gruyter

2020-05-18

Bloch-Trojnar, M \& Nurmio , S 2020 , Introduction to Celtic languages . in L Körtvélyessy , A pÿBagasheva \& $\mathrm{P}$ `tekauer (eds), Derivational Networks Across Languages. Trends in Linguistics. Studies and Monographs [TiLSM] , vol. 340 , de Gruyter , Berlin , pp. 295-298 . https://doi.org/10.1515/9

http://hdl.handle.net/10138/318015

https://doi.org/10.1515/9783110686630-029

unspecified

acceptedVersion

Downloaded from Helda, University of Helsinki institutional repository.

This is an electronic reprint of the original article.

This reprint may differ from the original in pagination and typographic detail.

Please cite the original version. 


\section{Celtic}

\section{Maria Bloch-Trojnar (Irish) \& Silva Nurmio (Welsh)}

Major complicating factors in the process of compiling derivational networks in Irish and Welsh are pervasive surface homonymy and functional ambiguity inherent in the terms 'verbal noun' (VN) and 'verbal adjective' (VA) employed in traditional grammars. The decision where to draw the dividing line between inflection and word-formation is languagespecific. The question whether we are dealing with conversion or affix homonymy/polysemy can be resolved on system-internal grounds and has turned out not to be uniform in Irish and Welsh, which represent two distinct subgroups within the Celtic branch (Goidelic and Brittonic respectively).

The verbal noun (ainm briathartha) is one of the most complex categories of Irish grammar. It is used in all contexts where English uses a participle, infinitive or a deverbal noun. The same phonological word may play the role of a non-finite form and a nominalization. Ó hAnluain (1999) distinguishes between VNs proper (ainm briathartha ceart) which function as non-finite verb forms, and VNs which behave like ordinary nouns (gnáth-ainmfhocal), i.e. they can be preceded by the definite article an, are modified by typical nominal modifiers such adjectives, nouns in the genitive case or numerals and take plural and case inflection. However, he notes that category identification is not always obvious and many view this binary distinction as artificial on account of surface homonymy. According to Doyle (2001: 61) 'in cases like this, it is difficult to speak of derivation from one category to another, since it is not clear what the base is. Rather, one can say that a given lexical item is a member of two categories, and only the syntactic context will tell us which one is involved in a particular example'. The process of $\mathrm{VN}$ formation is most effectively accounted for by regarding the verbal root (rather than the verbal stem) as the base. ${ }^{1}$ It is exception-ridden since it involves about 20 morphophonological exponents of varying productivity (e.g. -(e)adh, -(i)ú, -t, -áil, -(e)amh, -(e)an, -úint, -int). In addition, due to dialectal variation, there may be more than one $\mathrm{VN}$ form associated with a given verbal root (e.g. seinn 'play' > seinm, seinniúint, seinnt). This is as if English nominalizations in -(at)ion, -ment, -al, -ure etc. additionally featured in non-finite contexts. However, this formal overlap/indeterminacy is not complete in that there are cases where the non-finite form and the nominalization differ (e.g. folaigh 'hide, cover, conceal' - folú 'hide.vN', folachán 'hiding, concealment', ól 'drink' > ól 'drink.vN, drink.N', ólachán 'drinking, drink'). Nominalizations in Irish appear to tally with the traditional view, in that there is a categorial process yielding nouns with the semantics 'act(ion) of Verb-ing', which show a systematic polysemy between an abstract action reading and more concrete meanings, such as result or object of activity. Therefore, for the purpose of this study, they are included in the derivational networks. However, an alternative analysis on which nominalizations are products of conversion cannot be definitely ruled out, a move which would diminish the derivational capacity of verbs. ${ }^{2}$

\footnotetext{
${ }^{1}$ For a detailed account of the morphophonology of VNs, the reader is referred to Bloch-Trojnar (2006, 2008).

2 There several reasons why the author of the chapter on Irish has decided not to follow the conversion analysis. She is not aware of the existence of an analysis where such a relationship is explicitly and convincingly argued
} 
In Welsh, verbal nouns are formed by a range of suffixes added to the base, often, but not always, distributed according to the stem vowel, e.g. car- $u$ 'love' and torr- $i$ 'break, cut'. For further discussion, see Russell (2015a; 1995: 260-277) and see Thomas (2006: 668-674) for a full list of suffixes. Each verb regularly has a VN as part of its paradigm, and these have both verbal and nominal characteristics, as they do in Irish. In their nominal uses, they can, for instance, occur with the definite article and be modified by adjectives. On the other hand, verbal nouns are used in the construction [auxiliary verb] + [aspect marker] + [verbal noun] (Russell 2015a: 1232-1236), e.g.

$\begin{array}{llll}\begin{array}{l}\text { mae } \\ \text { be.3SG.PRES.INDIC }\end{array} & \text { ef } & y n & \text { cerdded } \\ \text { 'he is walking' } & & \text { PRT } & \text { walk.VN }\end{array}$

Since VNs form a part of the paradigm of a verb, their nominal uses can be viewed as instances of conversion. Since conversion, or zero derivation, was excluded from the present study, VNs from verbal stems were not included in the derivational networks of Welsh verbs. However, there are also VNs built on nouns and adjectives, e.g. duo 'turn black, darken (verbal noun)' from $d u$ 'black (adjective)' (see the chapter on Welsh for further discussion). These are clear instances of derivation and were included in the Welsh networks.

'Verbal adjectives' (VAs) corresponding in part to past participles in e.g. Germanic languages also warrant further discussion, e.g. Irish póg-tha 'kissed' and Welsh rhodd-edig 'given' (Ó Siadhail 1989: 198-200; Evans 1964: 165-166; see Russell 1995: 276, n. 2 for a comprehensive list of references). Whereas past participles in languages like English were excluded from this study, since their adjectival uses can be argued to be the result of conversion from the verbal form, it can be argued that synchronically the past participles in Welsh are adjectives derived from a verbal stem, and not the result of conversion. This is because the past participles no longer feature in fully 'verbal' contexts, but rather they have been superseded by a construction using the verbal noun. See the chapter on Welsh in this volume for further discussion.

In Irish, on the other hand, the VA is still regularly used in verbal contexts. It discharges the role of the past/perfective participle and is used with the verb 'to be' to express the passive perfective aspect and it also appears in resultative structures (Ó Sé 2004: 197; Doyle 2009: 144-146). In its adjectivized guise, the perfective participle, like any adjective,

\footnotetext{
for. $\mathrm{VN}>\mathrm{N}$ conversion poses serious formal, functional and semantic difficulties. The formation of infinitives in German or gerunds in English involves only one formal marker (-en and -ing respectively) and the corresponding nouns show uniform actional semantics and belong to a single inflectional class. In Irish, there is a multitude of formal markers, it is not immediately evident which non-finite category should act as the base (the infinitive or present participle), the out-put is integrated into several declension classes (Carnie 2008) and the semantics of nouns shows the process/event-result/object dichotomy. Furthermore, there are some complex issues relating to the relationship between abstract nouns with actional semantics and VNs, which seem to point to the opposite direction, i.e. N > VN conversion (Ó Cuív 1980, Wigger 1972: 209-212). There is no denying that VNs act as non-finite verb forms. However, to avoid the vexing question of directionality it seems preferable not to regard nominalizations as derivationally related to them, as proposed by Doyle (2001), but to derive them form verbal bases, as suggested in Ó hAnluain (1999: 250), who lists VN formal markers in the section on word-formation.
} 
Pre-publication version

For the definitive version, see https://doi.org/10.1515/9783110686630-029

may appear predicatively after the copula or else fulfill an attributive function as a nominal postmodifier. In contrast to VNs, in morphological terms, the form of the VA is regular and productive and the addition of the two suffixes involved (-ta/-te, -tha/-the) is fully predictable from the phonological properties and the conjugation class of the verb. This prompts an analysis on which such adjectives in Irish are products of conversion and as such are not included in the derivational networks.

In some derivational categories in Irish we can observe a formal and semantic affinity with VNs and VAs. Such cases are treated as $1^{\text {st }}$ order deverbal derivatives and there are two equally plausible analyses. We can recognize the existence of the verbal stem in -ta/-te, -tha/the, which is also deployed in derivation or allow for more affix allomorphy (e.g. treating thóir and -tóir as allomorphs of -óir in the formation of deverbal Agent nouns). Consider some examples of the categories in question, where the derivative can be related to either the root or the extended stem:

1. agentive gearr, gearrtha 'cut'> gearrthóir 'cutter', ól, ólta 'drink' > óltóir 'drinker'

2. quality dóigh, dóite 'burn'> dóiteach 'burning, scorching; bitter, severe, annoying'

3. ability ól, ólta 'drink'> so-ólta 'drinkable'

4. abstraction cas, casta 'twist' > castacht 'complexity, intricacy'

5. resultative gearr, gearrtha 'cut' > gearrthóg 'cutting, snippet, cutlet'

In summary, the difficult categories for creating derivational networks in Irish and Welsh were the so-called verbal nouns and verbal adjectives, which straddle the boundary between inflection and derivation. While sharing many characteristics, they also differ significantly between the two languages, leading to different decisions by the authors of the Irish and Welsh chapters in this volume: Welsh verbal nouns built on verbal stems were excluded while verbal adjectives were included, whereas the opposite is the case for Irish.

\section{References}

Bloch-Trojnar, Maria. 2006. Polyfunctionality in Morphology. A Study of Verbal Nouns in Modern Irish. Lublin: Wydawnictwo KUL.

Bloch-Trojnar, Maria. 2008. The morphology of verbal nouns in Modern Irish. Éigse: A Journal of Irish Studies 36. 63-81.

Carnie, Andrew. 2008. Irish Nouns. A Reference Guide. Oxford: Oxford University Press.

Doyle, Aidan. 2001. Irish (Languages of the World/Materials 201). München: Lincom Europa.

Doyle, Aidan. 2009. Morphosyntactic change and the perfect passive of Irish. In Maria Bloch-Trojnar (ed.), Perspectives on Celtic Languages, 143-160. Lublin: Wydawnictwo KUL.

Evans, Simon D. 1964. A Grammar of Middle Welsh. Dublin: Dublin Institute for Advanced Studies.

Ó Cuív, Brian. 1980. The verbal noun ending in -áil and related forms. Celtica 13. 125-145. 
Ó hAnluain, Liam. 1999. Graiméar Gaeilge na mBráithre Críostaí [Irish grammar by the Christian Brothers]. Baile Átha Cliath: An Gúm.

Ó Sé, Diarmuid. 2004. The 'after' perfect and related constructions in Gaelic dialects. Ériu 54. 179-248.

Ó Siadhail, Mícheál. 1989. Modern Irish: Grammatical Structure and Dialectal Variation. Cambridge: Cambridge University Press.

Russell, Paul, 1995. An introduction to the Celtic languages. London: Routledge.

Russell, Paul. 2015. Verbal nouns in Celtic. In Peter O. Müller, Ingeborg Ohnheiser, Susan

Olsen \& Franz Rainer (eds.), Word-Formation: An International Handbook of the

Languages of Europe, 1230-1241. Berlin \& Boston: Mouton de Gruyter.

Thomas, Peter Wynn. 2006. Gramadeg y Gymraeg [A grammar of Welsh], 3rd edn. Cardiff: University of Wales Press.

Wigger, Arndt. 1972. Preliminaries to a generative morphology of the Modern Irish verb. Ériu 23. 162-213. 